との鑑別は困難であり， ATL では治療前に既に fibrinogen, prekallikrein などの凝固因子の低下, 出 血傾向が見られた。2）PCA は APL，DICを伴う AML で著しい高值を示し, ALL の低 fibrinogen 血 漿例でも高值であった。PlgAA は低 fibrinogen 血症 の ALL で高值を示し, XAA ははっきりした傾向を 示さなかった。ELA は APL, CML で高值であり, ALL では低值傾向であった。CLA は ATL 等のリン パ性白血病で高值を取るものが存在した。また ATL homogenate は高濃度で凝固時間を延長させ， pre- kallikrein に対する抗凝固作用を有することが示唆さ れた。

考案 : リンパ系腫場疾患でも種々の凝血学的異常が出 現し，これらは細胞内に存在する種々の protease, 凝固因子に対する inhibitor の座生, 抗癌剂, 網内系 の処理能などの影響を受け生じることが推察された。 この凝血学的異常発生のメカニズムを検討すること は，患者の止血管理に重要であるとともに，基礎疾患 診断の手助けになり得ると考光られた。

$$
\begin{aligned}
& \text { シンポジウム II 「リポ蛋白代謝とマクロファージ」 } \\
& \text { 可会のことば } \\
& \text { 高 橋潔 熊本大学第 } 2 \text { 病理 } \\
& \text { 森芳 茂 兵庫医大第 } 1 \text { 病理 }
\end{aligned}
$$

Aschoff（1924）は網内系の概念を提唱するにあた り，彼の門下生である Landau \& NcNee (1914) が 明らかにしたコレステロール代謝上重要な役割を演ず る細胞群 (Milzapparat または endothelialer Stoffwechselapparat）が端緒になったことは周知のこと である。その後網内系の概念は広狭様々な変遷をして きたが，代謝異常に関しては主としてリピドーシスに ついての研究が行なわれてきた。最近マクロファージ がリポ蛋白に対するレセプターを有し，コレステロー ル代謝に特異的な役割を演じていることが明らかにさ れ, 動脈硬化症や黄色腫症を特徵付ける泡沫細胞の発 生機構に関する研究が飛躍的に進歩し, マクロファー ジのリポ蛋白代謝における重要性が浮き彫りにされつ つある。

この時期に「リポ蛋白代謝とマクロファージ」と題 してのシンポジウムが本学会で取り上げられることは 正に時を得たものであり，その意義は大きい。本シン
ポジゥムではリポ蛋白代謝とその異常に分け，それぞ れの状態でのマクロファージの役割について検討す る。1）リポ蛋白代謝に拈けるマクロファージの機能 について a) 最近注目を集めている化学的修飾を受 けた LDL に対するマクロファージの scavenger function と b) マクロファージからのコレステロ ールの排出機構に関する HDL とマクロファージの関 連をテーマに選んだ。リポ蛋白代謝異常におけるマク ロファージの機能については 2) ヒトの家族性高コ レステロール血症の動物モデルである LDL レセプタ 一久損ウサギ（WHHL rabbit）を用い，その病態解 析と $\beta$-VLDL の取り込みを中心に，3）人体例では a ) 黄色腫症や b ) 動脈硬化症の泡沫細胞発生過程 を臨床的, 超微形態学的ならびに生化学的方面からの 多角的かつ病因的解析が試みられる。発表は現在第一 線で御活躍中のエキスパートに打願いした。 


\title{
1.リポ螢白代謝に㧍けるマクロファージの役割
}

a.リポ蛋白及び化学修飾リポ蛋白に対するマクロファージの認識機構

\author{
明内 正公 \\ 捙本大学第二生化学:
}

動脈硬化アテローム巣の泡淋細胞 (Foam cells) は 細胞内コレステロールェステル蓄積を特徵とする。こ の蓄積メカニズムの解明はこれまで動脈硬化研究の主 流をなしてきた。泡沫細胞の由来については平滑筋細 胞, マクロファージ（以下 $\mathrm{M} \phi$ ) の二説があるが，少 なくとも動脈硬化初期病变の泡沫細胞形成には $\mathrm{M} \phi$ が主役を演じていると考兄られる。また, 臨床疫学的 所見は代表的なコレステロール運搬りポ蛋白である L DL（低密度リポ蛋白）と動脈硬化との密接な関係を 支持している。以上の背景から LDL とM $\phi$ の相互作 用が動脈硬化発症の要因として注目されるに至った。 先ず第一に, Goldstein と Brown によって明確にさ れた LDL レセプターを介する生体認識系が有力候補 として浮かび上がった。しかしこのレセプターは一 般に $\mathrm{M} \phi$ 系細胞には発現されないこと, 更に, 遺伝 的に本レセプターを欠損した家族性高コレステロール 血症患者には若年から著明なアテローム病変が出現す ることから, LDL が $\mathrm{M} \phi$ に直接取り込をれる可能性 は極めて薄いと考学られる。従って, 取り込まれる経 路としては，(1)生体内で何等かの修飾を受けた LDL が $\mathrm{M} \phi$ から認識され取り込まれる（リガンド側の变 化）あるいは，(2)アテローム巣で M $\phi$ にDLを取 り込む様な機能的変化が生じる（細胞側の変化）の二 つ考光られる。特に前者の可能性について LDLをア 七チル化するとマウス腹腔 $\mathrm{M} \phi$ から活発な取り达み を受け典型的な泡沫細胞を形成する発見 2 を契機にし て化学修飾蛋白に対するレセプター介在エンドサイト ーシス機構 (スカベンジャー機構) が動脈硬化の病態
に迫るものとして注目されるようになった。

このアセチル化 LDL の取り达久を担う $\mathrm{M} \phi$ のスカ ベンジャ一経路の概略を下図に示した。細胞膜レセプ ターは一般にアセチル LDL レセプターと総称され， ○つの特徵を見いだすことが出来る。第一は非修飾蛋 白 LDLを全く認識しないことであり，第二は $\mathrm{M} \phi$ 及 び $\mathrm{M} \phi$ 系細胞に特異的に発現されることである。こ のスカベンジャーレセプターのリガンドとして現在, アセチル化 LDL, マロンジアルデヒト修飾 LDL, マ レイル化アルブミンなどが知られている。これらのリ ガンドは腹腔 $\mathrm{M} \phi$ 及び肝臓類润細胞によってレセプ ター介在エンドサイトーシス機構で活発に取り込まれ る。本シンポジゥムではこの現象の特異性を担ら細胞 膜レセプターの蛋白化学的性状及びリガンド認識特異 性から，M $\phi$ のコレステロール蓄積系におけるスカべ ンジャ一経路の意義について考察したい。

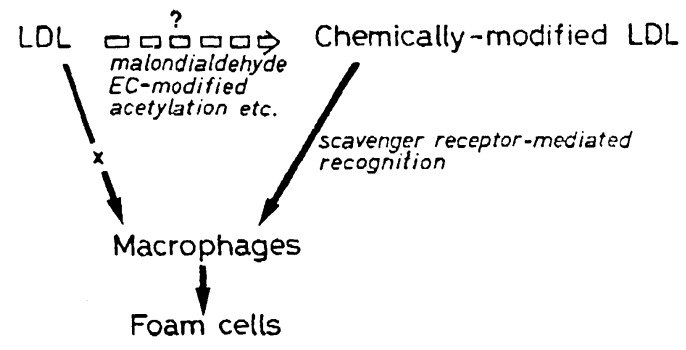

スカベンジャーレセプターを経由するマクロフォ 一ジの泡沫化機構 
b. マクロファージに発現される HDL レセプターと HDL の細胞内動態

\author{
福 田 精 二. \\ 熊本大学第二病理
}

今日生体内コレステロール運搬体である低密度りポ 蛋白 (LDL) は動脈硬化の惹起因子として重視され, 高密度リポ蛋白 (HDL) は防御因子として臨床疫学的 に位置つけられている。コレステロールの細胞内蓄積 は主としてマクロファージ $(\mathrm{M} \phi)$ に発現し, 動脈硬 化症や黄色腫病变を形成する。その際注目される LD L の細胞内への取り込みと細胞内代謝経路は LDL レ セプターやスカベンジャーレセプタ一の面から可成り 解明が進められている。一方, これに対して, HDL は末梢組織から肝へのコレステロール運搬を担い, 細 胞レベルでは細胞内コレステロールの排出機構に関与. する。 M $\phi$ に拈いても $\mathrm{HDL}$ は蓄積コレステロール の細胞外排出に関与するが，その詳細な機序は現在な お不明である。このような現状からわれわれは $\mathrm{M} \phi$ に対する HDL の役割を明らかにする目的で，培善ラ ット腹腔 $\mathrm{M} \phi$ を用い, $\mathrm{HDL}$ との相互作用を電顕的, 生化学的に検索し, 種々の標識 HDL について比較検 討しているので，その概要を紹介する。

ヒト HDL (アポ E-free) を金コロイド, 西洋ワサ ビペルオキシダーゼ (HRP) およびフェリチンで標識 した三種類の HDL 複合体を作成し，それぞれを付着 $\mathrm{M} \phi$ と $4^{\circ} \mathrm{C}$ で保温して細胞結合を観察した後, さら に HDL を含まない培養液で $37^{\circ} \mathrm{C}$ に温度を上げて 経時的に細胞内動態を観察した。

金コロイド HDL 複合体は M $\boldsymbol{M}$ に低温で結合し, $75 \% か ゙$ coated pits, $25 \%$ smooth surface membrane に認められた。この結合は非標識 HDL で細 胞を前処理すると, 有意に阻害される。 $37^{\circ} \mathrm{C}$ にす と, 細胞表面の金コロイドは, 2 分で coated vesicles, tubular structures さらに multivesicular endosomes (MVE) に移行し，5-10分ではほとんど が MVE に観察され，20分では80\%の粒子が dense bodies 内に認められる。dense bodies は細胞化学的
に非特異性エステラーゼ反応陽性で, さらにエンドゾ ームとライソゾームの瘉合が起こらない $16^{\circ} \mathrm{C}$ で培 差すると, 金コロイドの MVEから dense bodies へ の移行が阻害される。

HRP 標識 HDL では結合と取り込みの起こる 5 分 までは coated pit-coated vesicle system, tubular structures, MVE K HRP 反応産物が観察され, 金 コロイド $\mathrm{HDL} と$ 同一の経路を辿った。しかし，5一 10分で HRP 標識 HDL はゴルジ装置の trans 側の 小胞内に, さらに20-30分では分泌小胞と思われる小 型小胞に移行し，60分では細胞内にほとんど認められ なくなり，前記金コロイドの場合と対照的にライソゾ ームには僅かにしか観察されなかった。フェリチン標 識 HDL \& HRP 標識 HDL と同様の挙動を示した。 $\mathrm{HDL}$ が M $\phi$ 細胞膜に結合し, MVE, ゴルジ装置 を経由し, 細胞外へ分泌される経路は細胞に鉄を供給 するトランスフェリンの細胞内動態とよく類似して拉 り，その異同についても述べる。

放射ヨード標識 HDL を用いた生化学的解析を行う と, 標識 $\mathrm{HDL}$ は $4^{\circ} \mathrm{C}$ で $\mathrm{M} \phi$ への特異的結合を示 す。 $37^{\circ} \mathrm{C}$ に保温すると, 経時的に細胞内へ取り込ま れる量は増加するが, 有意なライソゾーム分解は検出 できなかった。標識 $\mathrm{HDL}$ と $37^{\circ} \mathrm{C}$ で保温後, メデ ィウム中の標識 HDL を除き, さらに保温すると, HDL がメディウム中へ分泌された。

以上の結果からラット腹腔 $\mathrm{M} \phi$ は HDL に対する 特異的レセプターを有し，このレセプターを介して HDL 分子は細胞内に取り达まれる。取り込まれた HDL はライソゾームで分解を受けることなく, ゴル ジ装置を経由して分泌されると考えられる。こういっ た知見をもとに，M $\phi$ における HDL の特徵的な細胞 内経路とコレステロール輸送との関係について考察を 加光る。 


\section{LDL レセプタ一欠損ウサギの病態解析}

—ことにリポ蛋白代謝異常時におけるマクロファージの役割について—

北徹

京都大学第三内科

家族性高コレステロール血症（FH）はその病因が LDL レセプター欠損にある。生化学, 分子遺伝学的研 究から, 現在では LDL レセプターの構造括よび, FH

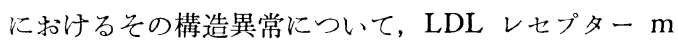
RNA の解析からかなりの部分, 分子レベルで明らか になってきている。ところが, LDL レセプター異常 が如何なる機構で FH の臨床的症状所見を呈してく るのであろらか。FH は遺伝形式が常染色体性優性遺 伝であり, 生下時より存在する内因性りポ蛋白 (VLD L, IDL, LDL) の上昇と, 早発性動脈硬化症, ことに 狭心症, 心筋梗塞などの虚血性心疾患を来すことが特 徵の疾患である。我々は, 上記問題につき, FH のモ デル動物である WHHL ウサギを用いて, in vivo, in vitro の系で次の事（11〜舟）を明らかにしてきた。 (1)WHHL ウサギは皮䖉線維芽細胞をはじめ, 実質細 胞飞 LDL レセプター異常が存在する。従って, WH HL ウサギと正常ウサギのリポ蛋白代謝を比較すれ ば， in vivo に抢ける LDL レセプターの役割が明ら かになる。(2)外因性りポ蛋白の代謝は, カイロミクロ ンを担体として行なわれているが，最終的には肝蔵の LDL レセプターとは遺伝的に異なるカイロミクロン レムナントレセプターを介して行なわれる。内因性り ポ蛋白代謝はどうであろうか。(3)因性りポ蛋白の代 謝は主に肝蔵の LDL レセプターを介して行なわれ るが, 肝蔵の LDL レセプターの数の減少, 欠損は $\mathrm{L}$ DL の産生過剩拉よび異化低下の相乗作用で高コレス テロール血症を惹起する。では一体, 血中に増加した 内因性リポ蛋白の上昇が LDL レセプターの欠損した FH, WHHL ウサギに如何なる機構で動脈硬化を惹起
するのであろらか。この paradox を解く 1 つの鍵と なったのがマクロファージ（M $\phi)$ のリポ蛋白代謝で ある。

動脈硬化初期病变に出現する泡沫細胞は, 血中由来 の $\mathrm{M} \phi$ であり，乙か子動脈硬化巣に蓄積する脂質組 成が血中 LDL の脂質組成と酷似していることが，多 くの研究者により示唆されている。我々は, in vitro でこの $\mathrm{M} \phi$ の泡沫化を試み, atherogenicなリポ蛋 白の解析及び $\mathrm{M} \phi$ への取り込久機構について検討し ている。(4)まず, WHHL ウサギで血中に増加した VL DL，IDL，LDL による効果を検討したところ，WHH L ウサギ VLDL, IDL はマウス腹腔内マクロファージ を泡淋化する。その取り込みは，レセプターを介して おり，LDLレセプターとは異なる $\beta$-VLDLレセプタ 一である。LDL レセプタ一の久損した WHHL ウサ ギ腹腔内 $\mathrm{M} \phi$ にも $\beta$-VLDL レセプターが存在する。 ところが, LDL は native な形では $\mathrm{M} \phi$ に認識され ない。LDL を化学的に修飾すると，例光ばアセチル 化，あるいは酸化を行なうと， $\mathrm{M} \phi$ はこれらをレセプ ターを介して取り込み，泡沫化する。以上，血中に増 加した内因性リポ蛋白は，M $\phi$ により， native な形 (WHHL-VLDL, IDL) で $\beta$-VLDL レセプターを介 して，あるいは，なんらかの修飾を受けて変性 LDL の形で，変性 LDL レセプターを介して取り込まれ， 泡沫化することが in vitro で明らかになった。今後， レセプターを介さない $\mathrm{M} \phi$ のリポ蛋白貪食作用, 及 び生体内に存在する変性 LDL の実態, おょび $\mathrm{M} \phi$ の 泡沫化が動脈硬化進展にどのように関るかにつき研究 を進めたいと考えている。 
3.リポ蛋白代謝異常とマクロファージ

a. 形態学的立場加

\author{
麻上千鳥
}

山口大皮膚科

リポ蛋白異常血症を伴った黄色腫症に薬物療法を行 い血清脂質值，血清蛋白電気泳動像の推移と皮疹の変 動を肉眼的, 病理組織学的および微細構造的に検討し た所見を対比してリポ蛋白と foam cell との関係につ いて述べる。

$\mathrm{V}$ 型, III 型高リポ蛋白血症, 正脂血症, midband 血症 (Mead and Dangerfield) ならびに II a 型高りポ 蛋白血症患者に Clofibrate $750 \mathrm{mg} /$ day を投与して検 索した。

\section{治療前の黄色丘疹および結節の組織像}

V型扎よび吕型高リポ蛋白血症の黄色丘瘆では表皮下 ～真皮全層に Sudan III陽性の脂質滴を有する foam cell の均一な浸潤がみられた。正脂血症, midband 血 症の黄色丘疹では表皮下〜真皮全層に紡錘形細胞，巨 細胞拉よ゙゙リンパ球を伴なう foam cell の浸潤がみ られた。II a 型高リポ蛋白血症の結節では真皮深層の 線維束が均一無構造化した部, 線維束間の開大部およ び開大した線維束間の foam cell の浸潤がみられた。

治療経過中の血清脂質值およびリポ蛋白電気泳動像 の推移と組織像

$\mathrm{V}$ 型の脂質值の変動をみると治療前のコレステロー ル (TC) 值は $590 \mathrm{mg} / \mathrm{dl}$, トリグリセライド (TC) 值 は $1750 \mathrm{mg} / \mathrm{dl}$ であったが，Clofibrate 投与. 2 \%月目 では TC 值は $269 \mathrm{mg} / \mathrm{dl}$, TG 值は $336 \mathrm{mg} / \mathrm{dl}$ と低 下した。丘疹は扁平化し典型的な foam cell は消褪 し，それに代り主として紡錘形を呈し Sudan III 染色 陰性の細胞浸潤がみられた。この推移をりポ蛋白面か らみるとカイロミクロンおよび Pre- $\beta$ L ps 縞の巾の縮 小をみたが，V型の電気泳動像のパターンには変動を みなかった。

III型の脂質値は治療前の TC 值は $403 \mathrm{mg} / \mathrm{dl}$ と高 值を示したが TG 值は $281 \mathrm{mg} / \mathrm{dl}$ と軽度高值を示し た。Clofibrate 投与1.5ヶ月（44日）目では TC 值は $294 \mathrm{mg} / \mathrm{dl}$ へと低下し, TG 值は $140 \mathrm{mg} / \mathrm{dl}$ となっ た。丘疹は扁平化し，真皮全層の foam cell は血管 周囲性に限局し，紡錘形細胞に混じて認められた。電 気泳動像のパターンの変動は夕られなかった。
正脂血症, midband 血症では TC および TG 值 は共に正常であった。Clofibrate 投与 4 ヶ 月（120日） 目では丘疹は扁平化し, 治療前の真皮全層の多彩な細 胞浸潤を伴った foam cell は乳頭下層へと限局して いた。 8 ヶ（240日）目では褐色斑化したが foam cell は核消裉し紡錘形細胞へと代っていた。電気泳 動像は治療前の UMCM 像 (Mead and Dangerfield) から CMLM ついで LM 像へと変動した。foam cell の消褪は CMLM および CM の変動と一致していた。

II a 型では Clofibrate 投与中に脂質值ならびに電気 泳動像に変動はみられなかった。foam cell から紡鉷 形細胞への移行もみられなかった。

治療経過中の foam cell および紡錘形細胞の微細 構造

V 型にみられた foam cell は治療前では明らかな限 界膜を示さず内部は均一に低電子密度な空胞状の脂質 滴を内包していたのに対し，治療により小型あるいは 屚平化した丘疹の残存した foam cell の脂質滴は限界 膜が明らかであり内部に高電子密度の顆粒状構造, あ るいはこれらの内容物の他に多層性配列を示す膜様構 造をそれぞれ含もものからなっていた。foam cell の 他には脂質空胞を $1 \sim 2$ 個含む組織球性と考えられる 細胞, 多数の低電子密度の不整形構造物を含さ脂質空 胞を含生平滑筋細胞様細胞, 線維芽細胞様細胞等が認 められた。

III 型では foam cell は均一・に低電子密度な空胞状の 脂質滴および高電子密度の脂質滴を内包していた。扁 平化した丘疹の残存した foam cell や foam cell の 他にみられた細胞はV型のそれにほぼ似ていた。光顕 的に V 型および血型で認められた紡錘形細胞は微細構 造的に組織球性細胞, 平滑筋様細胞および線維芽細胞 様細胞であった。

正脂血症, midband 血症の foam cell も III 型と同 様の構造を示したが LM-Lps を伴う時期 (Clofibrate 8 个月目) では pericyte および平滑筋細胞が脂質を 内包し細胞の変性像がみられた。脂質滴を内包しない マクロファージも認められた。 
b. 動脈硬化に関する病因的解析

11本章

国立循環器病センター研究所病因部

\section{1）擞状動脈硬化巣の成立とマクロファージ}

脂質を蓄積して動脈壁における䋆状硬化巣 atherosclerotic vasculer lesions の形成に関与する主たる 細胞種は平滑笳細胞とマクロファージである。平滑筋 細胞が動脈壁個有の細胞であるのに対して, マクロフ アージは血流から内皮障害部位，あるいは新生した毛 細血管を通して侵入して来た単球に由来する。雨種の 細胞は電子顕微鏡下の（周辺の線維を含む）形態観察 や，特異抗体との反応，あるいはエラスターゼなどの 特徵的な酵素の染色によって区別される。

中等度以上（コレステロール值 $280 \mathrm{mg} / \mathrm{d} 1$ 以上）の 高脂血症が思春期に存在する場合はアキレス腱などの 腱に黄色腄 Xanthoma（結節性）が，また極度の高脂 血症 (コレステロール值 $450 \mathrm{mg} / \mathrm{dl}$ 以上，またはトリ グリセライド值 $1000 \mathrm{mg} / \mathrm{dl}$ 以上）では皮膚に黄色腫 が出来る。この様な黄色腫はほડ゙すべてマクロファー ジから出来て居て, 動脈洣状硬化の一部を代弁してい る。

障害を受けた内膜に侵入したマクロファージが脂質 を蓄積して泡沫細胞 foam cell (fatladen cell) 飞変 って行く各段階を，ヒトの剖検標本を材料にして，電 子顕微鏡下に追跡した。泡沫細胞は脂質蓄積と共に細 胞内小器官がそしくなり，やがて破たんして内容は間 質にばらまかれる。しかし中には，新しく侵入した単 球マクロファージが, 破たんに瀕した泡沫細胞に接触 してこれを貪食しようとする像も見られた。洣状動脈 硬化巣では細胞外に（間質に）多量の脂質が存在する のに対して黄色腫では殆んどの脂質が細胞内に川:って いることや，コレステロールが下った場合に黄色腫が 速かに退縮するのは, 細胞種の違いによる（平滑筋細 胞は単球マクロファージの様に scavenger 機能をう まく発揮出来ない）と推測される。

\section{2）ママクロァージによる脂質代謝}

マクロファージには LDL レセプターを介するコレ ステロールの取込みは少いか, あるいは全くなく, 変 性 LDL，あるいは $\beta$-VLDL と呼ばれる異常組成のリ ポ蛋白を盛んに取込む機能がある。これについては北
徽博士が詳しく述べられるであろらので, 私の方は省 略する。

マクロファージはリポ蛋白リパーゼを分泌する。ヒ 卜単球性白血病細胞から cell line 化された THP-1 を用いた田嶋, 池田らのデータによれば, フォルボー ルエステルでマクロファージ化することによりリパー ゼの分泌が誘導される。このリパーゼはリポ蛋白の卜 リグリセライドを分解し，遊離脂肪酸（そしておとら くモノグリセライド）として細胞内に取り込むのに働 いていると考えられる。

マクロファージは自力でかなりのコレステロールを 合成する。その多くは層状構造をもつ封入体の形成に 使われるらしい。特殊な薬物によって層状封入体は著 明に増加するが，コレステロールと並んでその重要な 成分を成すリン脂質中にはリソソームに特異とされる bis (monoacylglyceryl) phosphate が多く含まれる。 糊状硬化宩を作る細胞の中にもこの様な層状封入体が しばしば見つかる。

3）アポリポ蛋白 $\mathbf{E} 介$ 介すコレステロールの放出

マクロファージ細胞質中にたまったコレステロール は, マクロファージ自体が合成して分泌するアポリポ 蛋白 $\mathrm{E}$ とン脂質の複合体に移され, アポリポ蛋白 A-I を含む高密度りポ蛋白 HDL に乗せられて血流 に移行し，肝臓に逆輸送（返送）されると考号られて いる。組織球性リンパ腫由来の細胞を用いて, メディ ウム中にアポ $\mathrm{E} を$ 加えるだけで，細胞内に蓄積された コレステロールが充分放出されることを確認した。

4）抗コレステロール薬またはプラスマフェレーシス 療法によって, 黄色腫や粥状硬化巣は退縮しうる

ヒドロキメチルグルタリル CoA 還元䤃素拮抗阻害 剂である ML-236B の極大量投与に上って, 黄色腫の 急速な退縮を認めた。またプロブコールは常用量で黄 色腄の著明な退縮をおこす。先に挙げた 2 種のマク口 ファージ細胞系を用いて，in vitroで， medium 中に 添加したプロブコールが変性 LDL (acetyl LDL) に よるマクロファージへの脂質蓄積を抑制することを証: 明した。血清コレステロールをプラスマフェレーシス 
によって思い切って下げることによっても黄色腫, 粥 状硬化巣の退縮を和こしうる。家族性高コレステロー ル血症ホモ接合体に見られる大動脈弁の変化が速かに
改善されるのも，この部に存在する細胞がマクロファ ージ由来である（平滑筋細胞がない）ためと推測され る。臨床例の幾つかを供覧する。 